Volume 3 Nomor 2, Agustus 2018, halaman 159-170

\title{
PERBANDINGAN KEMAMPUAN PEMAHAMAN MATEMATIS SISWA ANTARA YANG MENGGUNAKAN MODEL PEMBELAJARAN KOOPERATIF TIPE GROUP INVESTIGATION DENGAN TIPE MARRY GO ROUND
}

\section{COMPARISON OF MATHEMATICS UNDERSTANDING ABILITY OF STUDENTS BETWEEN USING COOPERATIVE LEARNING MODELS GROUP INVESTIGATION TYPE WITH MARRY GO ROUND TYPE}

\author{
Casmunah $^{1}$, Sri Hartini ${ }^{2}$, Denni Ismunandar ${ }^{3}$ \\ ${ }^{1}$ SMKN 1 Widasari, Jl. By Pass Ujungjaya Desa Ujungjaya Widasari Indramayu 45271, \\ casmunah_math@yahoo.co.id \\ ${ }^{2,3}$ Universitas Wiralodra, Jl. Ir. H. Djuanda km.3 Singaraja Indramayu 45213, \\ hartini5511@unwir.ac.id,denni.ismunandar@unwir.ac.id
}

\begin{abstract}
ABSTRAK
Tujuan penelitian ini untuk mengetahui gambaran kemampuan pemahaman matematis siswa yang pembelajarannya menggunakan model pembelajaran kooperatif tipe Group Investigation dan tipe Marry Go Round, serta kemampuan pemahaman matematis siswa yang menggunakan model pembelajaran kooperatif tipe Group Investigation lebih baik daripada tipe Marry Go Round. Penelitian ini adalah penelitian eksperimen, dengan populasi seluruh siswa kelas VII SMP Negeri 3 Jatibarang Tahun Pelajaran 2017/2018. Sampel kelas diambil sebanyak dua kelas dengan menggunakan teknik cluster random sampling dengan cara diundi. Berdasarkan uji hipotesis dengan menggunakan uji-t, diperoleh bahwa kemampuan pemahaman matematis siswa yang menggunakan model pembelajaran kooperatif tipe Group Investigation lebih baik daripada tipe Marry Go Round. Dengan demikian, model pembelajaran kooperatif tipe Group Investigation dapat diterapkan oleh guru sebagai alternatif pembelajaran matematika untuk membangkitkan kemampuan pemahaman matematis siswa.
\end{abstract}

Kata Kunci: Kemampuan Pemahaman Matematis, Model Pembelajaran Kooperatif, Group Investigation, Marry Go Round

\begin{abstract}
The purpose of this research is to know The description of student's ability of mathematical understanding by using cooperative learning Group Investigation (GI) and Marry Go Round, Students mathematical understanding ability by using cooperative learning Group Investigation (GI) type better than Marry Go Round type. This research is experimental research, with the population is all of students in the first grade of Junior High School 3 jatibarang academic year 2017/2018. The sample class was taken by using cluster random sampling technique in a drawing. Based on hypothesis by using t-test, we can obtained that there is students mathematical understanding ability by using cooperative learning Group Investigation (GI) type better than Marry Go Round type.
\end{abstract}

Keywords: Mathematics Understanding Ability, Cooperative Learning Model, Group Investigation, Marry Go Round 
160 Perbandingan Kemampuan Pemahaman Matematis Siswa Antara yang Menggunakan Model Pembelajaran Kooperatif Tipe Group Investigation dengan Tipe Marry Go Round

How to Cite: Casmunah, Hartini, S., \& Ismunandar, D. (2018). Perbandingan Kemampuan Pemahaman Matematis Siswa Antara yang Menggunakan Model Pembelajaran Kooperatif Tipe Group Investigation dengan Tipe Marry Go Round. Mathline: Jurnal Matematika dan Pendidikan Matematika, Vol.3, No.2, 159-170.

\section{PENDAHULUAN}

Pendidikan merupakan salah satu dari beberapa faktor penentu kemajuan suatu bangsa, karena dengan pendidikan yang berkualitas akan mencetak generasi yang berguna bagi nusa, bangsa dan agama. Pemerintah mengupayakan pendidikan berkualitas yang menjadi permasalahan saat ini, terbukti dengan adanya pembaharuan kurikulum KTSP menjadi kurikulum 2013 yang diterapkan sebagian besar sekolah di Indonesia bertujuan untuk siswa berperan secara aktif dalam pembelajaran. Akan tetapi, pada tahun 2017 pemerintah berupaya untuk mengevaluasi kurikulum 2013 dengan bertujuan menyempurnakan kurikulum tersebut menjadi kurikulum 2013 revisi 2017.

Menurut beberapa siswa, sebagian besar mengalami hambatan dalam memahami pelajaran seperti halnya pelajaran matematika. Matematika menjadi momok yang menakutkan bagi sebagian siswa, karena terdapat hambatan-hambatan yang mungkin dihadapi oleh siswa dalam memahami materi matematika. Berdasarkan konsultasi dengan guru matematika di SMP Negeri 3 Jatibarang bahwa hambatan-hambatan dalam memahami matematika bisa disebabkan oleh beberapa faktor, diantaranya: (1) Pemahaman konsep; (2) Motivasi belajar; (3) Kesiapan belajar; (4) Gaya belajar; (5) Kuantitas latihan; (6) Penempatan jam belajar; (7) Sumber belajar; (8) Kualitas kegiatan non belajar; (9) Metode belajar; (10) Model pembelajaran; (11) Media pembelajaran; (12) Minat siswa dan masih banyak faktor lainnya. Dari beberapa faktor di atas, peneliti hanya mengambil 2 faktor untuk dijadikan pertimbangan pada penelitian ini yaitu: pemahaman konsep dan model pembelajaran.

Menurut Sumarmo (Rohendi, 2015) bahwa, "Pemahaman diartikan sebagai penyerapan arti suatu materi yang di pelajari”. Kemampuan pemahaman matematis siswa merupakan faktor penting dalam pembelajaran, karena dengan adanya pemahaman siswa dapat menuangkan ide-ide secara matematis yang berguna untuk mengerjakan permasalahan matematika. hal ini sejalan dengan pendapat dengan pendapat Laelasari \& Ratnasari (2013) bahwa, "Kemampuan pemahaman matematis adalah kemampuan yang harus dimiliki siswa dalam mencapai tujuan dari pembelajaran, dimana materi-materi yang disampaikan kepada siswa bukan hanya sekedar hafalan, namun lebih dari itu siswa harus 
paham tentang konsep materi pelajaran itu sendiri dan bagaimana pengaplikasian konsep tersebut untuk menyelesaikan masalah".

Adapun menurut Minarni, dkk. (2016) menyatakan bahwa, "Mathematical understanding as well as mathematical representation is an integral part of mathematical problem solving, while problem solving is the hearth of doing mathematics".

Berdasarkan menurut beberapa ahli diatas, dapat disimpulkan bahwa kemampuan pemahaman matematis siswa adalah pembelajaran yang memberikan pengetahuan kepada siswa terhadap konsep, memahami ide - ide matematika serta bagaimana mengaplikasikan konsep untuk menyelesaikan masalah.

Sedangkan model pembelajaran yang digunakan dapat mempengaruhi tujuan pembelajaran yang akan dicapai, oleh karena itu model pembelajaran berguna untuk membantu siswa dalam memahami materi. Adapun model pembelajaran yang digunakan oleh peneliti yaitu menggunakan model pembelajaran kooperatif tipe Group Investigation dan tipe Marry Go Round.

Menurut Majid (2015) bahwa, "Pembelajaran kooperatif adalah model pembelajaran yang mengutamakan kerjasama untuk mencapai tujuan pembelajaran". Pembelajaran koopeartif (cooperative learning) merupakan bentuk pembelajaran dengan cara siswa belajar dan bekerja dalam kelompok-kelompok kecil secara kolaboratif yang anggotanya terdiri dari 4 sampai 6 orang, dengan struktur kelompok yang bersifat heterogen.

Menurut pendapat Slavin (Fathurrohman, 2015) bahwa "cooperative learning refer to a variety of teaching methods in which students work in small groups to help one another learn academic content”. Hal ini sejalan dengan pendapat Slavin (Tran, 2014) bahwa, cooperative learning comprises "Instructional methods in which teachers organize students into small groups, which then work together to help one another learn academic content".

Berdasarkan pendapat ahli diatas, dapat di simpulkan bahwa pembelajaran kooperatif atau cooperative learning adalah model pembelajaran secara berkelompok, dimana siswa saling bekerjasama untuk mencapai tujuan dari pembelajaran itu sendiri. Menurut Huda (2015) bahwa, "Model pembelajaran kooperatif Group Investigation adalah suatu model pembelajaran kooperatif yang menekankan pada heterogenitas dan kerjasama antar siswa". Model ini memiliki manfaat untuk melatih siswa dalam menerima perbedaan pendapat dan bekerja dalam melakukan penyelidikan untuk memecahkan masalah bersama-sama dengan siswa lain yang mempunyai latar belakang berbeda. 
162 Perbandingan Kemampuan Pemahaman Matematis Siswa Antara yang Menggunakan Model Pembelajaran Kooperatif Tipe Group Investigation dengan Tipe Marry Go Round

Hal ini sejalan dengan pendapat Siregar \& Motlan (2012) yang menyatakan bahwa, "Group Investigation merupakan salah satu model pembelajaran kooperatif dimana para siswa secara kolaboratif dalam kelompoknya memeriksa, mengalami dan memahami topik kajian yang akan di pelajari”. Model ini memiliki manfaat untuk melatih siswa dalam menerima perbedaan pendapat dan bekerja dalam melakukan penyelidikan untuk memecahkan masalah bersama-sama dengan siswa lain yang mempunyai latar belakang berbeda.

Adapun menurut Lestari \& Yudhanegara (2017) bahwa "Model pembelajaran Group Investigation menuntut semua anggota kelompok untuk merencakanan suatu penelitian beserta perencanaan penyelesaian masalah yang di hadapi”. Kelompok menentukan apa saja yang akan dikerjakan dan siapa saja yang akan melaksanakan dan bagaimana perencanaan penyajian di depan kelas. Adapun langkah-langkah model pembelajaran Group Investigation yaitu :

a) Teams yaitu pembentukan kelompok heterogen yang terdiri atas 5-6 siswa berdasarkan heterogenitas.

b) Identification yaitu guru menyediakan beberapa subtopik dalam bidang masalah secara umum. Setiap kelompok memilih subtopik yang di sediakan guru, kemudian mengidentifikasi topik tersebut untuk di teliti.

c) Planning yaitu siswa merencakan prosedur belajar tertentu untuk menyelesaikan masalah yang akan di teliti.

d) Investigation yaitu siswa melakukan penyelidikan dengan mengumpulkan, menganalisis dan mengevaluasi informasi yang telah dilakukan.

e) Final project yaitu setiap kelompok mempersiapkan tugas akhir terkait dengan investigasi kelompok yang telah dilakukan.

f) Presentation yaitu siswa mempresentasikan laporan tugas akhirnya di depan kelas.

g) Evaluation yaitu guru dan siswa mengevaluasi kontribusi masing-masing kelompok.

Dari pendapat ahli diatas, dapat disimpulkan bahwa model pembelajaran kooperatif Group Investigation adalah model pembelajaran kooperatif dimana semua anggota kelompok ikut berpartisipasi dalam hal menginvestigasi suatu permasalahan dan bertujuan untuk membangun kerja sama antar anggota kelompok itu sendiri.

Menurut Fathurrohman (2015) bahwa, "Model pembelajaran kooperatif tipe keliling kelompok ini memberikan kesempatan lebih banyak kepada siswa untuk dikenali dan menunjukkan partisipasi mereka kepada orang lain dalam pemecahan suatu permasalahan”. Pembelajaran kooperatif tipe keliling kelompok merupakan cara yang 
efektif untuk mengubah pola diskusi di dalam kelas yang akan mengaktifkan setiap anggota kelompok. Adapun menurut Fitri \& Yani (2017) bahwa, "Model pembelajaran Marry Go Round (keliling kelompok) yaitu setiap siswa didalam kelompok menanggapi tugas yang diberikan oleh guru, tugas tersebut berisikan masalah yang harus dicari jawabannya dengan cara berdiskusi”.

Adapun langkah-langkah Marry Go Round menurut Lie (Faturrohman, 2015) sebagai berikut:

a) Salah satu siswa dalam kelompok memulai dengan memberikan pandangan dan pemikirannya mengenai tugas yang sedang mereka kerjakan.

b) Siswa berikutnya juga ikut memberi tanggapan.

c) Demikian seterusnya, giliran bicara bisa dilaksanakan menurut perputaran arah jarum jam atau dari kiri ke kanan.

Menurut beberapa pendapat ahli atas, dapat disimpulkan bahwa model pembelajaran kooperatif tipe Marry Go Round adalah model pembelajaran secara kelompok dimana tujuan dari keliling kelompok ini untuk membangun partisipasi siswa secara aktif dalam keterlibatan menyelesaikan permasalahan.

\section{METODE PENELITIAN}

Penelitian ini adalah penelitian eksperimen, dengan populasi seluruh siswa kelas VII SMP Negeri 3 Jatibarang Tahun Pelajaran 2017/2018. Sampel kelas diambil sebanyak dua kelas dengan menggunakan teknik cluster random sampling, dimana kelas eksperimen I menggunakan model pembelajaran kooperatif tipe Group Investigation (GI) dan kelas eksperimen II menggunakan model pembelajaran kooperatif tipe Marry Go Round. Adapun instrumen yang mencakup untuk mengukur kemampuan pemahaman matematis siswa yaitu tes uraian sebanyak 5 soal dengan skor maksimum ideal 40. Oleh karena itu dalam penelitian ini peneliti menentukan variabel bebas yaitu model pembelajaran kooperatif tipe Group Investigation (GI) dan tipe Marry Go Round, sedangkan untuk variabel terikatnya adalah kemampuan pemahaman matematis siswa. Desain yang digunakan dalam penelitian ini, (Senjaya, 2017) adalah sebagai berikut:
$\mathrm{R}: \quad \mathrm{T}_{1}$
$\mathrm{O}$
$\mathrm{R}: \quad \mathrm{T}_{2}$
$\mathrm{O}$ 
164 Perbandingan Kemampuan Pemahaman Matematis Siswa Antara yang Menggunakan Model Pembelajaran Kooperatif Tipe Group Investigation dengan Tipe Marry Go Round

Keterangan:

$\mathrm{R}$ : Randomsasi pengambilan sampel

$\mathrm{T}_{1}$ : Treatment 1 (Perlakuan 1), yaitu penggunaan model pembelajaran kooperatif tipe Group Investigation

$\mathrm{T}_{2}$ : Treatment 2 (Perlakuan 2), yaitu penggunaan model pembelajaran kooperatif tipe Marry Go Round

O : Observasi

Adapun teknik pengolahan data kuantitatif dengan menggunakan rumuss statistika sebagai berikut:

1) Membuat daftar distribusi frekuensi.

2) Histogram.

3) Menentukan rata - rata dan varians.

4) Uji normalitas.

5) Uji homogenitas

6) Uji beda dua rata - rata atau uji $-\mathrm{t}$

\section{HASIL DAN PEMBAHASAN}

Sebelum menarik kesimpulan dari hasil penelitian yang dilakukan, terlebih dahulu peneliti melakukan uji normalitas bertujuan untk prasyarat uji parametrik dan untuk mengetahui sebaran data berdistribusi normal. Pada penelitian ini didapat hasill uji normalitas sebagai berikut:

Tabel 1. Hasil Uji Normalitas

\begin{tabular}{cccc}
\hline Kelas & $\chi^{2}$ hitung & $\chi^{2}$ tabel & Keterangan \\
\hline Eks I & 3,95 & 11,070 & Normal \\
Eks II & 4,63 & & Normal \\
\hline
\end{tabular}

Berdasarkan tabel di atas, menunjukkan bahwa pada kelas eksperimen I diperoleh $\chi^{2}$ hitung $=3,95$ dan $\chi^{2}$ tabel $=11,070$. Sedangkan kelas eksperimen II diperoleh $\chi^{2}$ hitung $=4,63$ dan $\chi_{\text {tabel }}^{2}=11,070$. Dengan taraf signifikansi $(a)=0,05$ dan derajat kebebasan $d k_{\text {eksperimen } \mathrm{I}}$ $=\mathrm{k}-1=6-1=5$ dan $d k_{\text {eksperimen } \mathrm{I}}=\mathrm{k}-1=6-1=5$. Karena $\chi^{2}$ hitung $<\chi^{2}$ tabel, $\mathrm{H}_{0}$ ditolak. Artinya sampel berasal dari populasi yang berdistribusi normal.

Setelah diketahui data tes kemampuan pemahaman matematis kelas eksperimen I dan kelas eksperimen II berdistribusi normal, maka dilanjutkan dengan uji homogenitas dua varians. Uji homogenitas menggunakan varians kelas eksperimen I dan kelas eksperimen II. Adapun hasil perhitungan diperoleh data sebagai berikut: 
Tabel 2. Data Uji Homogenitas Dua Varians

\begin{tabular}{ccccc}
\hline Kelas & $\mathbf{N}$ & Varians & $\mathbf{F}_{\text {hitung }}$ & F tabel \\
\hline Eks I & 30 & 61,41 & 1,15 & 1,86 \\
Eks II & 30 & 53,63 & & \\
\hline
\end{tabular}

Berdasarkan data diatas dengan taraf signifikan $(a)=0,05$ dan $d k_{1}=29$ dan $d k_{2}=$ 29, diperoleh $F_{\text {hitung }}=1,15$ dan $F_{\text {tabel }}=1,86$. Karena $F_{\text {hitung }}<F_{\text {tabel }}, H_{0}$ diterima maka berdasarkan kriteria uji homogenitas dapat disimpulkan data hasil tes akhir dari kedua kelompok memiliki varians homogen.

Setelah normalitas dan homogenitas dua varians dipenuhi, maka alternatif selanjutnya menguji beda dua rata-rata yaitu dengan menggunakan uji-t. Hal ini bertujuan untuk mengetahui ada tidaknya perbandingan kemampuan pemahaman matematis siswa antara yang menggunakan model pembelajaran kooperatif tipe Group Investigation dengan tipe Marry Go Round.

Tabel 3. Data Uji Perbedaan Dua Rata-rata

\begin{tabular}{cccccc}
\hline Kelas & Rata-rata & Varians & S $\mathbf{2}$ gab & thitung & \multirow{2}{*}{ tabel } \\
\hline Eks I & 22,70 & 61,41 & 57,52 & 2,35 & 2,00 \\
Eks II & 18,10 & 53,63 & & & \\
\hline
\end{tabular}

Berdasarkan tabel di atas, dengan taraf signifikansi $\mathrm{a}=0,05$ dan derajat kebebasan $(d k)=62$ diperoleh $t_{\text {hitung }}=2,35$ dan $t_{\text {tabel }}=2,00$. Karena $t_{\text {hitung }}>t_{\text {tabel }}$ maka $\mathrm{H}_{0}$ ditolak, berarti dapat disimpulkan bahwa terdapat perbedaan kemampuan pemahaman matematis antara siswa yang menggunakan model pembelajaran kooperati tipe Group Investigation dengan tipe Marry Go Round. Berdasarkan rata-rata kelas eksperimen I = 22,70 dan kelas eksperimen II = 18,10, maka rata-rata skor kemampuan pemahaman matematis siswa yang pembelajarannya menggunakan tipe Group Investigation terhadap materi Penyajian Data lebih baik daripada siswa yang menggunakan tipe Marry Go Round.

Berdasarkan analisis data di atas, kemampuan pemahaman matematis sangat perlu untuk dikembangkan, hal ini sesuai dengan pendapat Minarni (2016) yaitu perlu adanya usaha yang berkelanjutan untuk mengembangkan kemampuan pemahaman masalah. Kemampuan pemahaman matematis siswa merupakan salah satu tujuan pembelajaran matematika. Oleh karena itu kemampuan pemahaman matematis sangat penting untuk dimiliki oleh siswa, sehingga dengan memahami konsep akan membantu siswa untuk menyelesaikan persoalan matematika. Hal ini sesuai dengan Laelasari \& Ratnasari (2013) 
166 Perbandingan Kemampuan Pemahaman Matematis Siswa Antara yang Menggunakan Model Pembelajaran Kooperatif Tipe Group Investigation dengan Tipe Marry Go Round

bahwa siswa yang memiliki kemampuan pemahaman matematis dapat mengaplikasikan konsep untuk menyelesaikan permasalahan. Salah satu upaya untuk mengembangkan kemampuan pemahaman matematis siswa melalui model pembelajaran kooperatif.

Model pembelajaran kooperatif merupakan model pembelajaran secara berkelompok, dimana dalam pembelajaran ini siswa bekerja sama antar anggota kelompok untuk memahami materi yang disampaikan. Salah satu model pembelajaran kooperatif yang peneliti terapkan pada penelitian ini adalah dengan tipe Group Investigation dan tipe Marry Go Round.

Model pembelajaran kooperatif tipe Group Investigation membuat anggota kelompok lebih aktif dan kreatif dalam menyelesaikan masalah yang dihadapi kelompok, karena pada tipe ini siswa dituntut untuk memahami materi secara mandiri sehingga terjadi diskusi aktif. Ketika pembelajaran berlangsung pada kelas eksperimen I yang menggunakan model pembelajaran kooperatif tipe Group Investigation (GI), siswa bersemangat dalam mengerjakan soal yang diberikan. Temuan analisis penelitian ini sejalan dengan hasil penelitian Siregar \& Motlan (2016), bahwa model pembelajaran menggunakan tipe Group Investigation dapat mempengaruhi kemampuan siswa.

Sedangkan pada model pembelajaran kooperatif tipe Marry Go Round siswa saling bertukar informasi antar anggota kelompok untuk menyelesaikan permasalahan yang di hadapi kelompoknya, akan tetapi pada pembelajaran kooperatif tipe Marry Go Round terdapat beberapa siswa yang merasa sulit menyelesaikan permasalahan yang diberikan oleh guru karena terjadinya managemen waktu yang kurang efektif ketika pembelajaran berlangsung. Sehingga model pembelajaran kooperatif tipe Group Investigation lebih baik daripada tipe Marry Go Round. Hal ini terbukti pada lembar jawaban salah satu siswa berikut: 


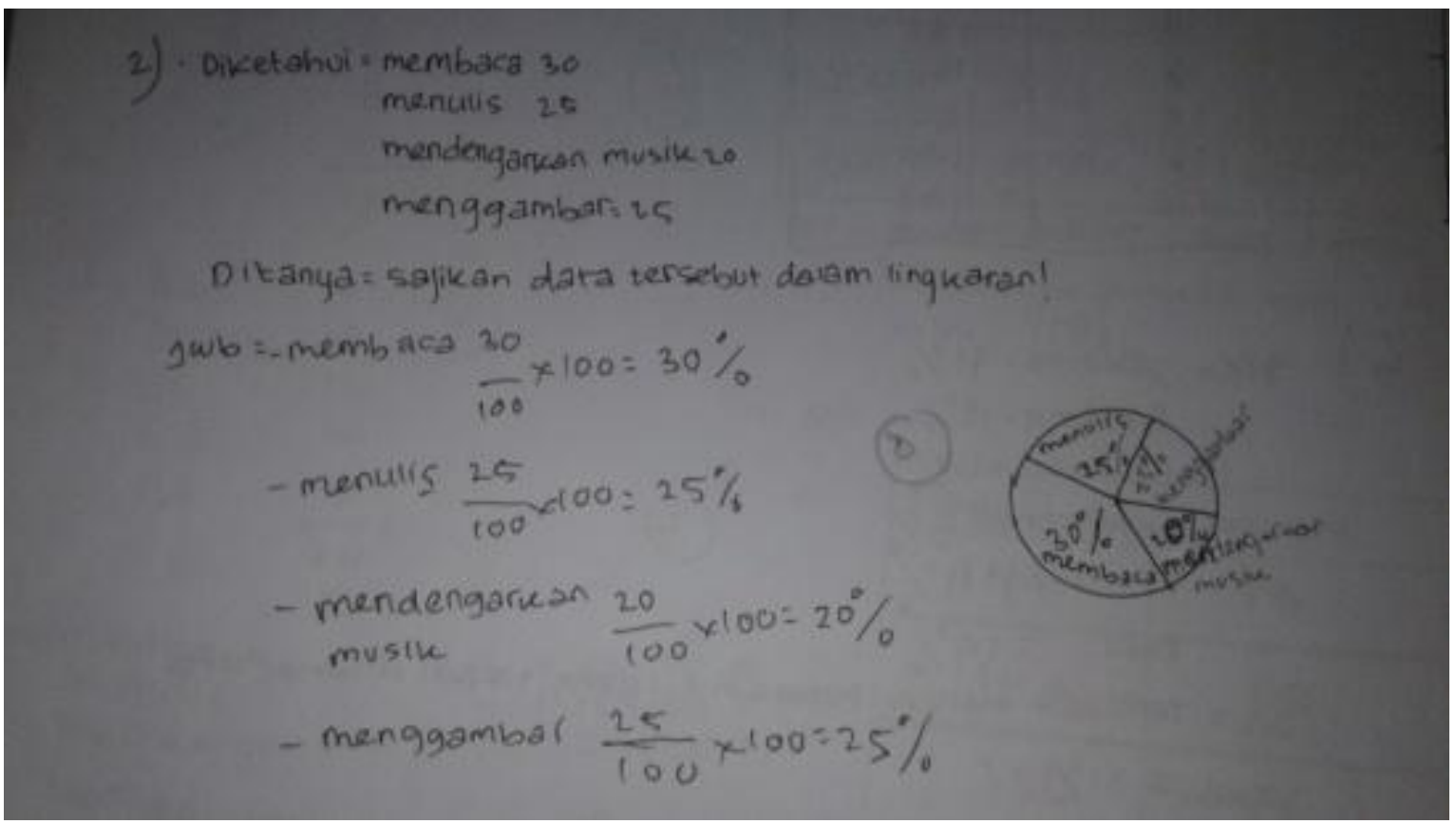

Gambar 1. Pengerjaan Siswa pada Kelas Eksperimen I

Pada gambar 1 siswa dapat mengidentifikasi kaitan antar konsep/prinsip, melaksanakan perhitungan namun belum mampu menyertakan alasan terhadap proses matematika yang di lakukan.

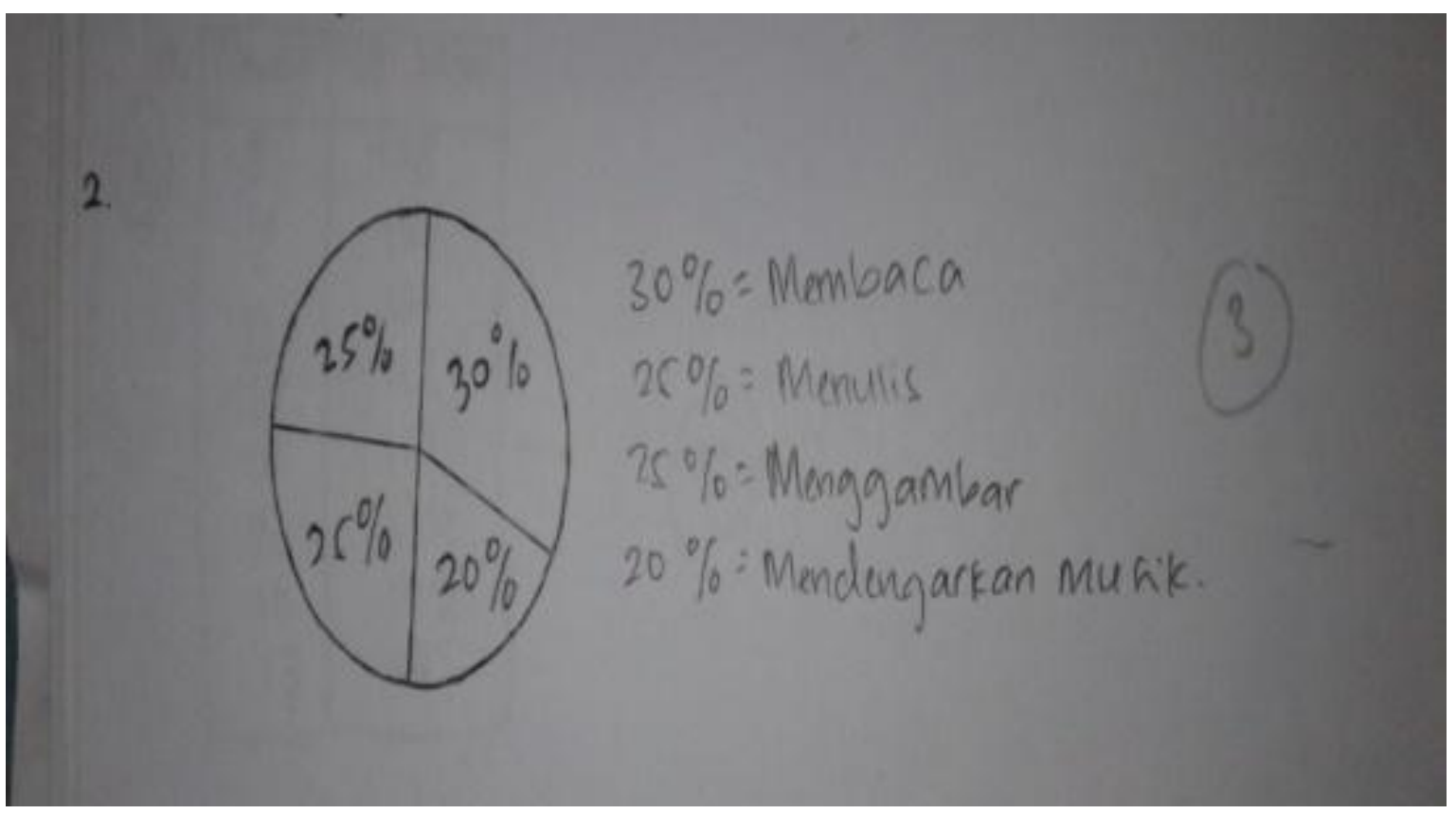

Gambar 2. Pengerjaan siswa pada kelas eksperimen II

Pada gambar 2 siswa belum mampu mengidentifikasi kaitan antar konsep/prinsip, melaksanakan perhitungan dan menyertakan alasan terhadap proses matematika yang di lakukan. Adapun kendala yang dihadapi peneliti ketika melakukan penelitian diantaranya: a) pengkondisian kelompok; b) Managemen waktu; c) Penyajian hasil diskusi kelompok. 
168 Perbandingan Kemampuan Pemahaman Matematis Siswa Antara yang Menggunakan Model Pembelajaran Kooperatif Tipe Group Investigation dengan Tipe Marry Go Round

Akan tetapi dalam pelaksanaan pembelajaran pada kelas eksperimen I yang menggunakan model pembelajaran kooperatif tipe Group Investigation siswa mampu bekerjasama dengan baik antar kelompok dalam menyelesaikan permasalahan yang diberikan guru, Sehingga terjadinya diskusi yang aktif dalam kelas tersebut dibandingkan dengan kelas eksperimen II yang menggunakan model pembelajaran kooperatif tipe Marry Go Round.

Sebagaimana yang dikemukakan pendapat ahli yang menjelaskan tentang pengertian model pembelajaran kooperatif tipe Group Investigation (GI) dengan tipe Marry Go Round yang bertujuan untuk siswa berpartisipasi secara aktif dalam pembelajaran, sehingga penting dalam mengatur kelas secara kondusif.

Berdasarkan hasil penelitian yang peneliti lakukan di kelas VII SMP Negeri 3 Jatibarang, diperoleh skor rata-rata kelas eksperimen I yaitu kelas dengan menggunakan model pembelajaran kooperatif tipe Group Investigation (GI) adalah 22,70 dan skor ratarata kelas eksperimen II yaitu kelas dengan menggunakan model pembelajaran kooperatif tipe Marry Go Round adalah 18,10. Dari skor rata-rata yang diperoleh, kelas eksperimen I lebih besar dibandingkan kelas eksperimen II, hal ini menunjukkan kelas eksperimen I lebih bersemangat dalam pembelajaran dibandingkan dengan kelas eksperimen II. Kemudian dari hasil uji hipotesis yaitu uji-t tes akhir diperoleh nilai $t_{\text {hitung }}=2,35$ dengan taraf signifikan $a=0,05$ didapat $\mathrm{t}_{\text {tabel }}=2,00$. Hal ini menunjukkan $\mathrm{t}_{\text {hitung }}>\mathrm{t}_{\text {tabel }}$ maka berdasarkan kriteria pengujian hipotesis $\mathrm{H}_{0}$ ditolak, artinya dalam penelitian ini kemampuan pemahaman matematis siswa yang menggunakan model pembelajaran kooperatif tipe Group Investigation (GI) lebih baik daripada tipe Marry Go round.

\section{KESIMPULAN}

Dari perhitungan uji beda dua rata-rata dengan Uji-t, hasil tes akhir diperoleh nilai $t_{\text {hitung }}=2,35$ dan $t_{\text {tabel }}=2,00$. Dari kriteria pengujian hipotesis, karena $t_{\text {hitung }}>t_{\text {tabel }}$, maka $H_{0}$ ditolak. Hal ini menunjukkan adanya perbedaan kemampuan pemahaman matematis siswa yang menggunakan model pembelajaran kooperatif tipe Group Investigation dengan tipe Marry Go round. Rata-rata kelas yang menggunakan model pembelajaran kooperatif tipe Group Investigation yaitu 22,70, sedangkan rata-rata kelas yang menggunakan model pembelajaran kooperatif tipe Marry Go Round yaitu 18,10. Berdasarkan hasil uji hipotesis dengan taraf signifikan $a=0,05$, dapat disimpulkan bahwa kemampuan pemahaman matematis siswa yang menggunakan model pembelajaran kooperatif tipe Group Investigation lebih baik daripada tipe Marry Go Round. 
Diharapkan guru matematika dalam menghadapi siswa dengan kemampuan heterogen dapat diterapkan model pembelajaran kooperatif Seperti tipe Group Investigation dan tipe Marry Go round. Kemungkinan siswa belum memahami materi yang dijelaskan oleh guru, maka dengan belajar tutor sebaya akan mempermudah siswa dalam memahami materi yang disampaikan.

\section{DAFTAR PUSTAKA}

Fathurrohman, M. (2015). Model - model Pembelajaran. Yogyakarta: Ar- Ruzz Media.

Fitri, R \& Yani, O. (2017). Penerapan Model Pembelajaran Round Club Terhadap Kemampuan Komunikasi Matematis Siswa. MES (Journal of Mathematics Education and Science), 2(2), 52 - 58.

Huda, M. (2015). Model - model Pengajaran dan Pembelajaran. Bandung: Refika Aditama.

Laelasari \& Ratnasari, I. (2013). Perbandingan Kemampuan Pemahaman Matematis antara Siswa yang Menggunakan Model Pembelajaran Problem Bsed Learning (PBL) dan Model Pembelajaran Group Investigation (GI) Pada Siswa Kelas VIII SMP Negeri 2 Jalaksana. Jurnal Euclid, 1(1), $14-21$.

Lestari, K. E. \& Yudhanegara, M. R. (2017). Penelitian Pendidikan Matematika. Bandung: Refika Aditama.

Majid, A. (2015). Strategi Pembelajaran. Bandung: PT Remaja Rosdakarya.

Minarni, A., Napitulu, E., \& Husein, R. (2016). Mathematical Understanding and Representation Ability of Public Junior High School in North Sumatra. Journal on Mathematics Education, 7(1), 43 - 56.

Rohendi, S. (2015). Penerapan Model Pembelajaran Kooperatif Tipe Think Pair Share untuk Meningkatkan Kemampuan Pemahaman Matematis dan Dampaknya Pada Self Confidence Siswa SMP. Jurnal Kajian Pendidikan dan Pengajaran, 1(1), 37 44.

Senjaya, A. J. (2017). Statistika Terapan untuk Penelitian Bidang Pendidikan dan Pengajaran. Indramayu: Fkipunwir Press.

Siregar, H. D. \& Motlan. (2016). Pengaruh Model Pembelajaran Kooperatif Group Investigation dan Pemahaman Konsep Awal Terhadap Keterampilan Proses Sains Siswa SMA. Jurnal Pendidikan Fisika, 5(1), 51 - 57.

Tran, V.D. (2014). The Effects of Cooperative Learning on the Academic Achievement and Knowledge Retention. International Journal of Higher Education, 3(2), 131 140. 
170 Perbandingan Kemampuan Pemahaman Matematis Siswa Antara yang Menggunakan Model Pembelajaran Kooperatif Tipe Group Investigation dengan Tipe Marry Go Round 